\title{
Effect of Replacing Cement with Factory Waste (Steel, Aluminum and Copper) on the Compressive Strength of Concrete
}

\author{
Hesham Alsharie ${ }^{1}$ \\ ${ }^{1}$ Department of Civil Engineering, Jerash University, Jerash, Jordan \\ Correspondence: Hesham Alsharie, Department of Civil Engineering, Jerash University, Jerash, Jordan. E-mail: \\ h.alsharea@jpu.edu.jo
}

Received: January 27, 2019

Accepted: February 18, 2019

Online Published: March 31, 2019

doi:10.5539/mas.v13n4p114

URL: https://doi.org/10.5539/mas.v13n4p114

\begin{abstract}
The steel, aluminum and copper waste from the factories has a negative effect on the environment. This study investigates the possible reuse of steel, aluminum and copper waste as a supplementary cementitious material and its effect on concrete properties. This paper proposes a model for the prediction of the compressive strength of cement concrete and mortar as the cement was replaced with steel, aluminum and copper waste with the following by weight percentages: $0 \%, 5 \%, 10 \%$, and $15 \%$. The tests performed in this paper are conducted to the following samples: $(50 * 50 * 50 \mathrm{~mm})$ mortar samples, $(150 * 150 * 150 \mathrm{~mm})$ concrete cubes, and $(150 * 300 \mathrm{~mm})$ concrete cylinders. Tests are performed at the periods of 7 and 28 days. The results show that the use of steel waste (Fe15\%) increased compressive strength of concrete by $18.5 \%$ and copper waste by $(\mathrm{Cu} 15 \%)$ increased it by $15.77 \%$, aluminum (A115\%) increased it by $12.95 \%$ and steel waste (Fe15\%) increases compressive strength of cement mortar by $9.55 \%$ as compared to pure mixing. Consequently, adding steel waste to concrete gives it a compressive strength of more than the double of its original strength.
\end{abstract}

Keywords: Steel $(\mathrm{Fe})$ and Aluminum $(\mathrm{Al})$, Copper $(\mathrm{Cu})$ waste, Cement, Compressive Strength

\section{Introduction}

Metals used in the construction industry serve a wide range of functions. The most common of them are carbon steel, aluminum, copper tubing and stainless steel, which each have their particular qualities and ideal uses. As a whole, however, these metals are ubiquitous in the world of buildings and architecture, in applications both small and large [1]. The use of industrial waste and secondary materials to produce cement and concrete, mortar is recommended because it helps to reduce the consumption of natural resources. Steel, Aluminum and Copper wasteitems created by the compound chemical industries if not appropriately arranged can cause environmental issues in the encompassing territories. Metals waste is a substance which is otherwise called a strong waste that could be promising in the development of the industry as an incomplete or aggregate substitution of concrete. Numerous specialists are currently discoveringthe likelihood of utilizing metals wastes as an incomplete part substitution of concrete and mortar. The primary objective of this paper is to ponder the mechanical properties of compressive strengthconcrete and mortar containing different metal wastes at varying ratios.

This paper presents the results of an experimental investigation on the effect of using Steel, Aluminum and Copper waste as cement replacement on mortar and concrete cubes and cylindrical samples. In this study we tested the possibility of using wastes of mineral substances such as Iron, Copper and Aluminum in process of the production of cement paste and concrete for purpose of testing impacts of substituting certain portions of cement with mineral waste substances on fresh and solid concrete's and cement paste endurance and performance. Also, cement concrete mixtures of cooper, iron and substances with portions of cement $(0 \%, 5 \%, 10 \%, 15 \%)$ has been prepared. We have collected these wastes in one whole mixture in $15 \%$ of cement for each. It is also done with reinforced concrete and cement paste for every mixture $25 \mathrm{Mpa}$. This study also searches the effectiveness of these wastes for 7-day and 28-day duration. It shows that Iron portions are more powerful than any other mineral portions distinctively as the following: $\mathrm{Al}<\mathrm{Cu}<\mathrm{Fe}$. 


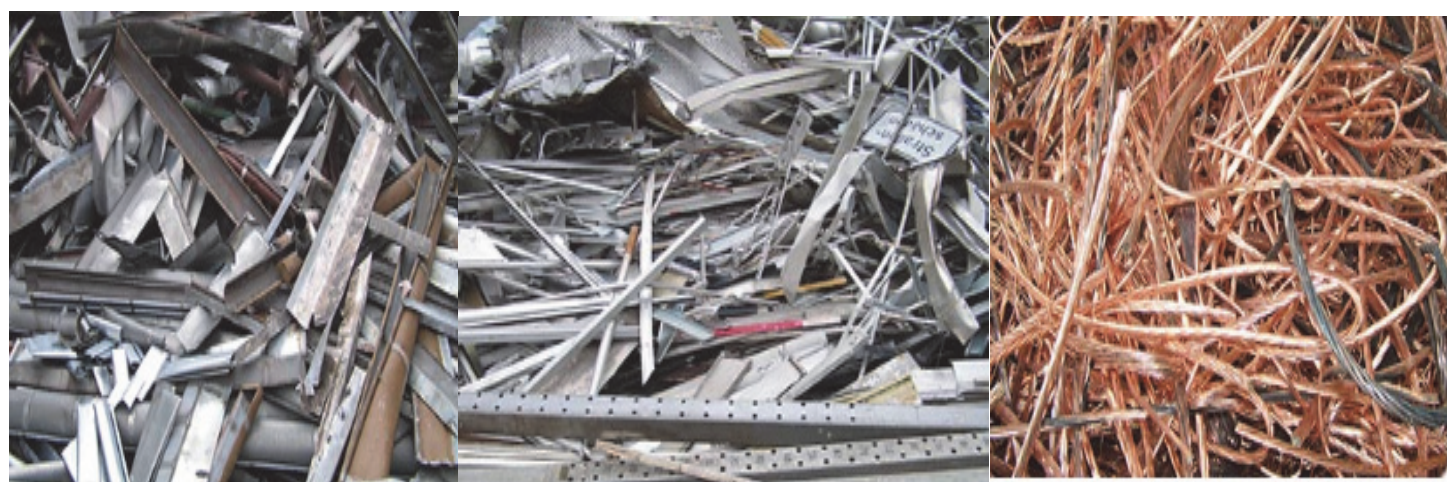

Figure 1. Steel waste $(\mathrm{Fe})$

Figure 2. Aluminum waste (AL)

Figure 3. Copper waste $(\mathrm{Cu})$

\section{Literature Review}

This literature review provides the necessary in this background information on concrete technology in general, along materials used for mortar and concrete manufacturing with a strong focus on concrete aggregate, the fine and coarse concrete aggregate are reviewed in terms of their properties, and the testing techniques used in the characterization of concrete aggregate are also reviewed.

Mortar is a workable paste used to bind building blocks such as stones, bricks, and concrete masonry units together, fill and seal the irregular gaps between them, and sometimes add decorative colors or patterns in masonry walls. In its broadest sense mortar includes pitch, asphalt, and soft mud or clay, such as used between mud bricks. Mortar comes from Latin mortarium meaning crushed [2].

Concrete is present including its acoustic characteristics with reference to coarse aggregate and conventional concrete, porosity has been identified as one of the most decisive properties affecting the physical, mechanical, and acoustic characteristics of concrete, subsequently, literature on porosity of coarse aggregate and concrete is reviewed [3].

The Concrete is a mixture of paste and aggregates (rocks). The paste is composed essentially of Portland cement and water, it coats the surface of the fine (small) and coarse (larger) aggregates. Through a series of chemical reactions called hydration, the paste hardens and gains strength to form the rock-like mass known as concrete [4].

With regard to the high importance of sustainable [5] development based on using green construction materials, many attempts have been made to adopt different strategies to implement sustainability in concrete industry and according to the World Commission on Environment and Development of the United Nations, sustainability is "meeting the needs of the present without compromising the ability of the future generations to meet their own needs" [6]. To encourage concrete industry for implementing sustainability aspects in its products and services, different organizations have published guidelines and specifications. In Australia, the Green Building Council of Australia (GBCA) has introduced Green Star Mat-4 which describes credits of concrete materials as mentioned earlier. In the meantime, Cement Concrete and Aggregates Australia (CCAA) published an industry guide for this document as referred to earlier [7]. According to GBCA and CCAA, a maximum value of three points is available in the Green Star rating system credit which have been developed for encouraging and recognizing positive steps in the reduction of greenhouse gas emissions, resource use and waste associated with the use of concrete. This credit system considers all types of concrete used in a project including structural and nonstructural concrete elements [8]. According to GBCA, it is possible to achieve up to two points where Portland cement content in all concrete used in a project has been reduced by replacing supplementary cementitious materials. Furthermore, there is another point which is related to the use of alternative coarse or fine aggregates as well as captured or reclaimed water [9].

The recycling of mineral waste in Jordan is minimal, Eng. Abd Al-Qutishat stated in an article in Al-Balad newspaper in 2016 "The recycling of waste has existed since ancient times in nature. The wastes of some organisms are considered to be food for other living organisms. Man has practiced the process of recycling waste since the Bronze Age, where he melted metal materials into new tools. Since many countries have taken care of environmental problems, many countries have taken measures to recycle wastes and limit the spread of hazardous waste. This has contributed to the protection of natural resources, the reduction of waste, the creation of new jobs, the protection of nature from pollution and the strengthening of the local economy through the provision of raw materials.Iron and steel form waste that can be recycled by $100 \%$ and for an infinite number of times, and this 
contributes to cover the needs of iron and steel plants. Iron scrap is an extremely important economic fact as it is a crude raw material on which the iron and steel industry is based. The scrap is transformed into real raw materials. This contributes to achieving advanced investment to benefit from the mineral wealth in the country and exploit it optimally. The process of recycling the iron to get rid of tons of abandoned iron and the remnants of cars and structures and rail, which is an environmental problem in our communities, and therefore conservation of natural resources, and the process of recycling to provide large amounts of funds for the purchase of raw materials in the iron industry, Smelting them into real raw materials.Aluminum is a low percentage of waste weight and weight but its high value makes it a target for waste recycling workers. Benefits of Recycling is aluminum Waste, aluminum waste recycling does not require any additional materials, the use of round aluminum provides $95 \%$ of the energy needed to manufacture raw materials and recycling $1 \mathrm{~kg}$ of aluminum leads to $8 \mathrm{~kg}$ of bauxite, $4 \mathrm{~kg}$ of chemicals and $14 \mathrm{~kW}$ of energy [10].

In this paper, the Steel, Aluminum and Copper wasteperplexing as substitution of some rate of bond is considered. Steel, Aluminum and Copperis a waste material which can be viewed as a pozzolanic material. In this section, an overview of previous research studies regarding the use of waste materials in concrete is discussed: Vaidya and Allouche evaluated the strain sensing of carbon fiber reinforced geopolymer concrete [11]. Brindha and Nagan evaluated the durability of the concrete mixed with copper slag [12]. The use of copper slag in cement was investigated by Nazer, Pavez and Rojas [13]. Onuaguluchi and Eren tested the durability characteristics of concrete mixtures containing copper tailings as an additive [14]. Naturals aggregates were replaced by slag products by Zeghichi [15]. Al-Jabri et al. used copper slag as sand replacement for high performanceconcrete [16]. Al-Jabri, Taha and Al-Saidy examined the effect of copper slag as fine aggregateon the characteristics of cement mortar and concrete with experimental work [17]. arzadnia, Abang and Demirboga examined the incorporation of mineral admixtures in sustainable high-performance concrete [18].

\section{Methodology}

To achieve these goals some experimental tests were conducted in order to obtain suitable amount of cement that gives improved mortar [19], and concrete properties, Samples were divided into nine categories according to the ratio of cement. Each category has three cubes and three cylindrical specimens that were prepared and tested, the categories were: cube specimens with null steel, aluminum and copper waste; cylindrical specimens with null steel, aluminum and copper waste; Cubes specimens with steel waste,cylindrical specimens with steel waste; Cubes specimens with aluminum waste, cylindrical specimens with aluminum waste; Cubes specimens with copper waste, cylindrical specimens with Copper waste; and cubes specimens with Steel, Aluminum and Copper waste. Test conducted on mortar and concrete after they were prepared were compressive tests [20], and slump tests [21]. 


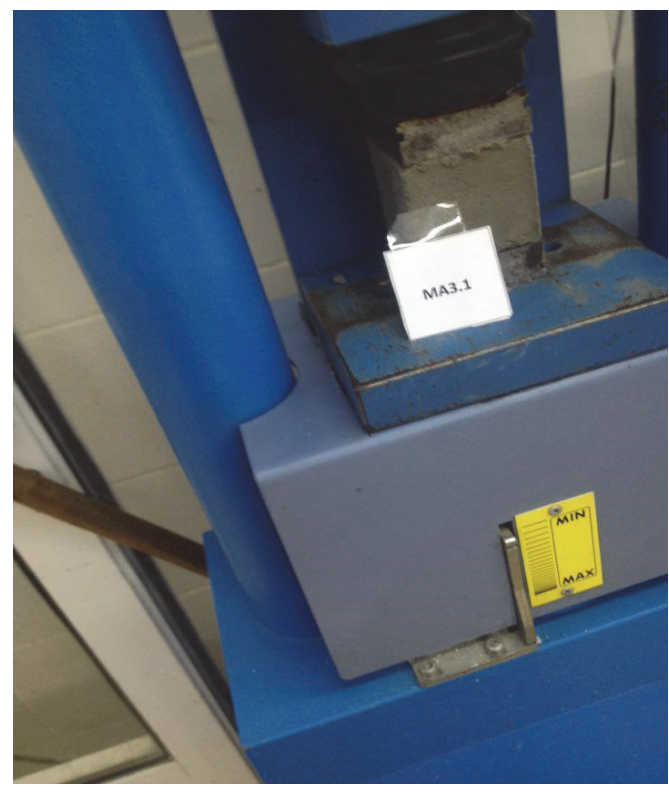

(a)

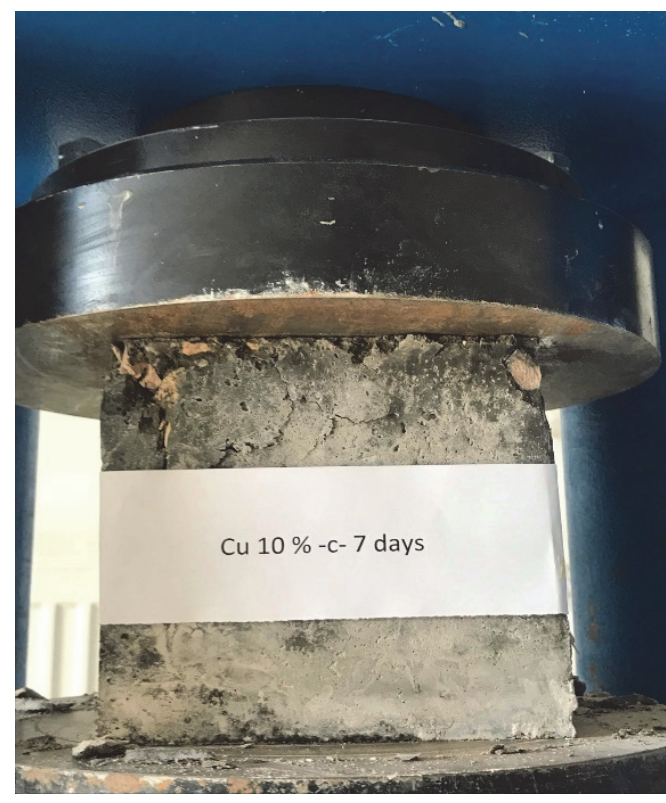

(b)

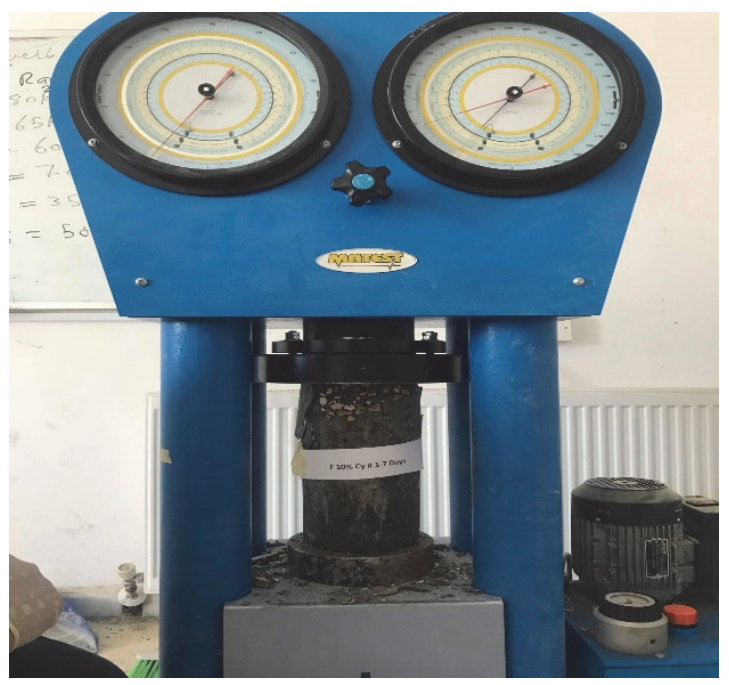

(c)

Figure 4. Compressive strength testing of (a) Aluminum waste mortar cubes (b) Copper waste concrete cubes (c) Steel waste concrete cylinders

In this section the preparation of mortar, concrete studied samples. Total of Forty-two (mortar), Sixty-six (cubes) And Forty-two (cylindrical) classified mortar, cylindrical and cubes were prepared.

First, all mortar samples were classified to four main categories: depending on the ratio ofcement $(\mathrm{Fe}, \mathrm{Al}, \mathrm{Cu})$ : Three cubes specimens with nullsteel, aluminum and copper waste (Fe, $\mathbf{A l}$ and $\mathbf{C u})$, Three cubes specimens with steel waste $(\mathrm{Fe})$, Three cube specimens with aluminum waste $(\mathrm{Al})$ and copper waste $(\mathbf{C u})$ is Cement(0.25gm):Sand(Fine)(0.7gm): water(0.125ml).

Note: P.M.7.1: First, Pure for mortar age seven days cube number one, Fe10\%. M.28.2: Adding 10\% ratio of cement weight and replaced with steel waste for mortar age twenty-eight days cube number two, Al15\%. M.7.3: Adding $15 \%$ ratio of cement weight and replaced with aluminum waste for mortar age seven days cube number three, Cu10\%. M.28.1: Adding 10\% ratio of cement weight and replaced with copper waste for mortar age twentyeight days cube number one.

Second, all concrete samples were, in addition to nine main categories of cubedepending on theratio of cement 
(P,Fe,Al,Cu):Three cubes specimens with nullsteel, aluminum and copper waste $(\mathrm{P}, \mathrm{Fe}, \mathrm{Al}, \mathrm{Cu})$, and three cubes specimens with ratio Steel waste $(5 \%, 10 \%$ and $15 \%)(\mathrm{Fe})$, Three cubes specimens with ratio aluminum waste $(5 \%, 10 \%$ and $15 \%)(\mathrm{Al})$, Three cubes specimens with ratio Copper waste $(5 \%, 10 \%$ and $15 \%)(\mathrm{Cu})$, Three cubes specimens with ratio steel, aluminum and copper waste $(15 \%)$ (Fe-Al-Cu), Three Cylindrical specimens with ratio null steel, aluminum and copper waste $(\mathrm{P}, \mathrm{Fe}, \mathrm{Al}, \mathrm{Cu})$, Three Cylindrical specimens with ratio Steel waste $(10 \%$ and $15 \%)(\mathrm{Fe})$, Three Cylindrical specimens with ratio aluminum waste (10\% and 15\%) (Al), Three Cylindrical specimens with ratio copper waste $(10 \%$ and $15 \%)(\mathrm{Cu})$.

Note: PC: Pure cube concrete, PCy: Pure cylindrical concrete, FeC: Steel waste cube concrete, FCy: Steel waste cylindrical concrete, AlC: Aluminum waste cube concrete, AlCy: Aluminum waste cylindrical concrete, CuC: Copper waste cube concrete, $\mathrm{CuCy}$ : Copper waste cylindrical concrete.

The following table $(1,2)$ gives the details of coarse and fine aggregate, and cement ratio that were used to prepare the specimens:

Table 1. The Mix Design Ratio Details of cube specimens

\begin{tabular}{cccccc}
\hline $\begin{array}{c}\text { Waste } \\
(\mathrm{Fe}, \mathrm{Al}, \mathrm{Cu}) \\
(\mathrm{kg})\end{array}$ & $\begin{array}{c}\text { Fine } \\
\text { aggregate } \\
(\mathrm{kg})\end{array}$ & $\begin{array}{c}\text { Coarse } \\
\text { aggregate } \\
(\mathrm{Kg})\end{array}$ & $\begin{array}{c}\text { Cement } \\
(\mathrm{kg})\end{array}$ & $\begin{array}{c}\text { Water } \\
(\mathrm{kg})\end{array}$ & $\begin{array}{c}\text { Waste } \\
(\%) \\
\text { Cement }\end{array}$ \\
\hline $\mathbf{0}$ & 8.046 & 10.44 & $\mathbf{3 . 6 7}$ & 1.824 & $\mathbf{0 \%}$ \\
$\mathbf{0 . 1 8 3 5}$ & 8.046 & 10.44 & $\mathbf{3 . 4 8 6}$ & 1.824 & $\mathbf{5 \%}$ \\
$\mathbf{0 . 3 6 7}$ & 8.046 & 10.44 & $\mathbf{3 . 2 3 3}$ & 1.824 & $\mathbf{1 0 \%}$ \\
$\mathbf{0 . 5 5 1}$ & 8.046 & 10.44 & $\mathbf{3 . 1 2}$ & 1.824 & $\mathbf{1 5 \%}$ \\
\hline
\end{tabular}

Table 2. The Mix Design Ratio Details of cylindrical specimens

\begin{tabular}{cccccc}
\hline $\begin{array}{c}\text { Waste } \\
(\mathrm{Fe}, \mathrm{Al}, \mathrm{Cu}) \\
(\mathrm{kg})\end{array}$ & $\begin{array}{c}\text { Fine } \\
\text { aggregate } \\
(\mathrm{kg})\end{array}$ & $\begin{array}{c}\text { Coarse } \\
\text { aggregate } \\
(\mathrm{Kg})\end{array}$ & $\begin{array}{c}\text { Cement } \\
(\mathrm{kg})\end{array}$ & $\begin{array}{c}\text { Water } \\
(\mathrm{kg})\end{array}$ & $\begin{array}{c}\text { Waste } \\
(\%) \\
\text { Cement }\end{array}$ \\
\hline $\mathbf{0}$ & 8.4 & 10.87 & $\mathbf{3 . 8 2 2 5}$ & 1.9 & $\mathbf{0 \%}$ \\
$\mathbf{0 . 3 8 2 3}$ & 8.4 & 10.87 & $\mathbf{3 . 4 4 0 2}$ & 1.9 & $\mathbf{1 0 \%}$ \\
$\mathbf{0 . 5 7 3}$ & 8.4 & 10.87 & $\mathbf{3 . 2 4 9 5}$ & 1.9 & $\mathbf{1 5 \%}$ \\
\hline
\end{tabular}

\section{Results and Discussion}

The compressive strength test result

Table 3. The Averagecompressive strength of cement mortar forSteel, Aluminum and Copperwaste (P,F,Al,Cu)

\begin{tabular}{ccc}
\hline Samples & $\begin{array}{c}\text { Average (MPA) } \\
\text { 7.day }\end{array}$ & $\begin{array}{c}\text { Average (MPA) } \\
\text { 28.day }\end{array}$ \\
\hline Pure & 17.6 & 25.7 \\
Fe-m-10\% & 30.13 & 32.2 \\
Fe-m-15\% & 33.06 & 35.6 \\
Al-m-10\% & 23.4 & 27.3 \\
Al-m-15\% & 28.1 & 30.4 \\
Cu-m-10\% & 27.8 & 29.6 \\
Cu-m-15\% & 29.3 & 32.1 \\
\hline
\end{tabular}




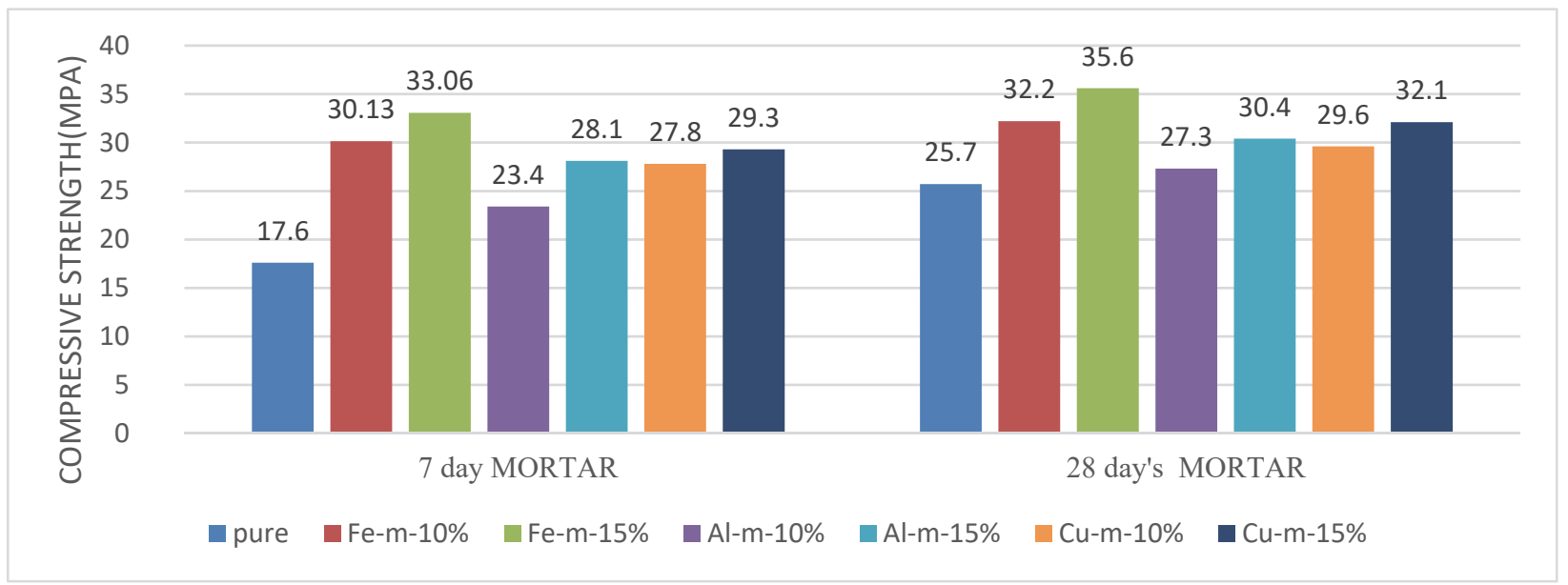

Figure 5. Average Compressive strength that conducted on the mortar for Steel, Aluminum and Copper waste $(\mathrm{P}, \mathrm{Fe}, \mathrm{Al}, \mathrm{Cu})$

Table 3 and figure 5 shows the results of compressive strength of cement mortar specimens at an age of 7 and 28 days. Results showed that the steel waste increased the compressive strength of cement mortar by a ratio of $44.18 \%$ and $24 \%$ at an age of 7 and 28 days, respectively. The compressive strength of cement mortar with aluminum wasteat an age of 7 and 28 days increased by a ratio of $31.1 \%$ and $10.7 \%$, respectively, and also copperwaste increased the compressive strength of cement mortar by a ratio of $38.31 \%$ and $16.57 \%$ at an age of 7 and 28 days as compared with pure mortar.

Table 4. The Average compressive strength of concrete cubes and cylindrical for Steel, Aluminum and Copper waste $(\mathrm{P}, \mathrm{Fe}, \mathrm{Al}, \mathrm{Cu})$

\begin{tabular}{|c|c|c|c|c|}
\hline \multirow[t]{2}{*}{ Samples } & \multicolumn{2}{|l|}{ Cubes (C) } & \multicolumn{2}{|c|}{ Cylindrical (Cy) } \\
\hline & Average (MPA) & Average (MPA) & Average (MPA) & Average (MPA) \\
\hline & 7.day & 28.day & 7.day & 28.day \\
\hline Pure & 17.9 & 25.2 & - & -... \\
\hline Fe-c- $5 \%$ & 21.18 & 26.96 & ---- & ---- \\
\hline Fe-c-10\% & 22.81 & 27.85 & --_-- & -.-- \\
\hline Fe-c-15\% & 24.58 & 30.81 & ---- & ---- \\
\hline Al-c-5\% & 18.07 & 25.92 & ---- & ---- \\
\hline Al-c-10\% & 20.29 & 26.51 & ---- & ---- \\
\hline Al-c-15\% & 22.81 & 28.83 & ----- & ----- \\
\hline $\mathrm{Cu}-\mathrm{c}-5 \%$ & 19.4 & 26.68 & ----- & ----- \\
\hline Cu-c-10\% & 21.47 & 26.81 & ----- & ----- \\
\hline Cu-c-15\% & 23.55 & 29.92 & ----- & ----- \\
\hline Fe.Al.Cu-c-15\% & 25.62 & 30.8 & ---- & ---- \\
\hline Pure-cy- & ----- & ---- & 13.9 & 21.33 \\
\hline Fe-cy-10\% & ---- & ---- & 18.81 & 23.9 \\
\hline Fe-cy-15\% & ----- & ---- & 18.6 & 26.83 \\
\hline Al-cy-10\% & ---- & ---- & 16.3 & 22.53 \\
\hline Al-cy-15\% & ---- & ---- & 18.81 & 24.83 \\
\hline Cu-cy-10\% & ---- & ---- & 17.48 & 22.67 \\
\hline Cu-cy-15\% & ---- & ---- & 18.81 & 25.96 \\
\hline Fe.Al.Cu-cy-15\% & ----- & ----- & 24.86 & 27.4 \\
\hline
\end{tabular}




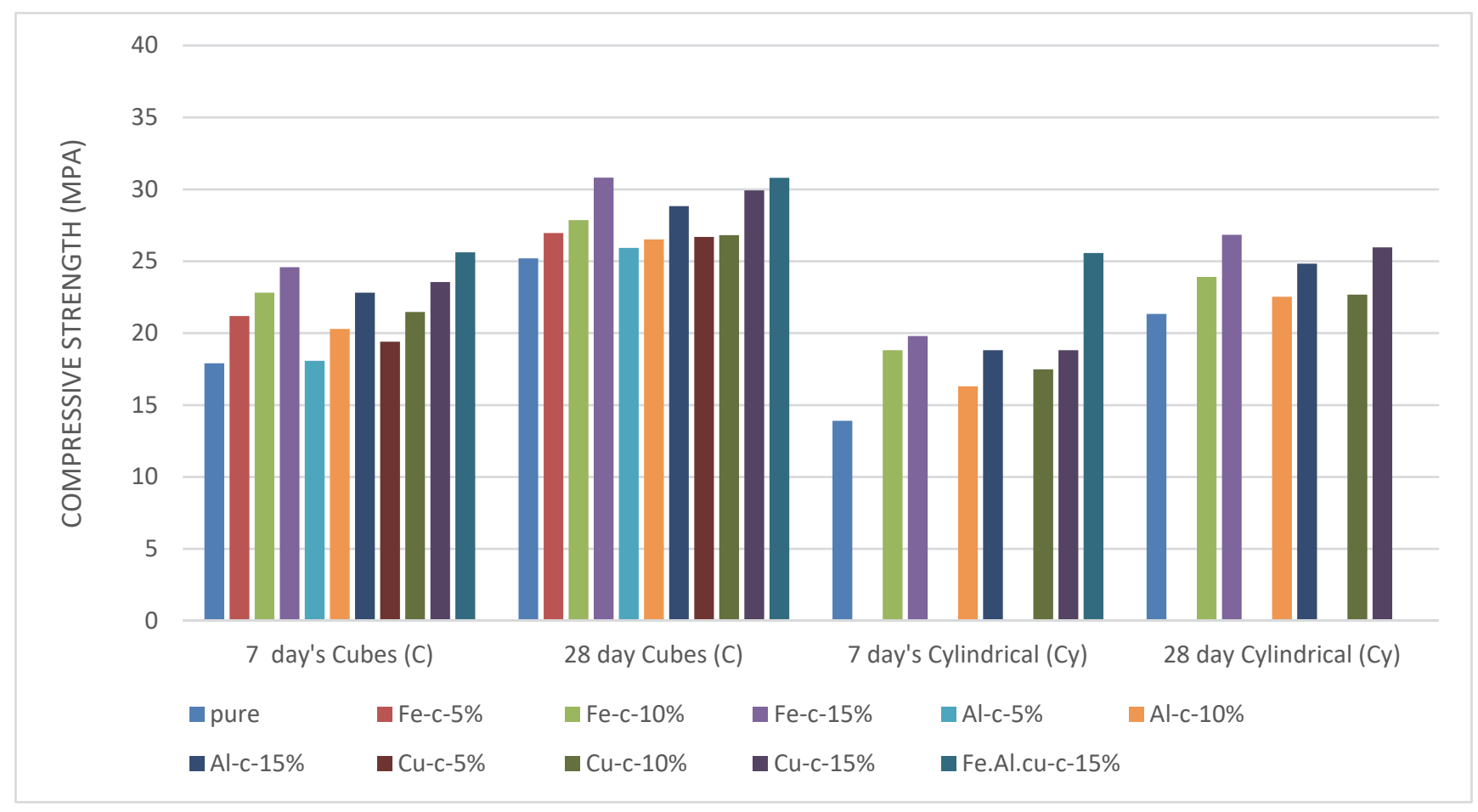

Figure 6. Average Compressive strength that conducted on the concrete cubes and cylindrical for Steel, Aluminum and Copper waste $(\mathrm{P}, \mathrm{Fe}, \mathrm{Al}, \mathrm{Cu})$

Table 4 and figure 6 show the results of compressive strength of concrete cubesand cylindrical at an age of 7 and 28 days. Results showed compressive strength of concrete cubes that the steel waste of cement ratio $5 \%, 10 \%$ and $15 \%$ increased the compressive strength of concrete cubes by a ratio of $15.51,21.5$ and $27.2 \%$ respectively at an age of 7 days. The compressive strength of concrete cubes with steel waste of cement ratio $5 \%, 10 \%$ and $15 \%$ increased the compressive strength of concrete cubes by a ratio of $6.5,9.5$ and $18.2 \%$ respectively at an age of 28 days, and compressive strength of concrete cubes that the aluminum waste of cement ratio $5 \%, 10 \%$ and $15 \%$ increased the compressive strength of concrete cubes by a ratio of $0.94,11.78$ and $21.5 \%$ respectively at an age of 7 days ,the compressive strength of concrete cubes with aluminum waste of cement ratio $5 \%, 10 \%$ and $15 \%$ increased the compressive strength of concrete cubes by a ratio of $2.78,4.94$ and $12.59 \%$ respectively at an age of 28 days , and also compressive strength of concrete cubes that the Copper waste of cement ratio $5 \%, 10 \%$ and $15 \%$ increased the compressive strength of concrete cubes by a ratio of $7.7,16.6$ and $23.99 \%$ respectively at an age of 7 days , the compressive strength of concrete cubes with copper waste of cement ratio $5 \%, 10 \%$ and $15 \%$ increased the compressive strength of concrete cubes by a ratio of 5.55, 6 and $15.77 \%$ respectively at an age of 28 days, compressive strength of concrete cubes that had the steel, aluminum and copper waste of cement ratio $15 \%$ increased the compressive strength of concrete cubes by a ratio of $30.13 \%$ respectively at an age of 7 days, the compressive strength of concrete cubes with steel, aluminum and copper waste of cement ratio $15 \%$ increased the compressive strength of concrete cubes by a ratio of $18.18 \%$ respectively at an age of 28 days as compared with pure concrete.

As for cylinders the compressive strength of concrete cylinders with Steel waste of cement ratio $10 \%$ and $15 \%$ increased the compressive strength of concrete cylinder by a ratio of 26.1 and $25.3 \%$ respectively at an age of 7 days. The compressive strength of concrete cylinder with steel waste of cement ratio $10 \%$ and $15 \%$ increased the compressive strength of concrete cylinder by a ratio of 10.75 and $20.5 \%$ respectively at an age of 28 days, and the compressive strength of concrete cylinders with aluminum waste of cement ratio $10 \%$ and $15 \%$ increased the compressive strength of concrete cylinder by a ratio of 14.7 and $26.1 \%$ respectively at an age of 7 days. The compressive strength of concrete cylinder with aluminum waste of cement ratio $10 \%$ and $15 \%$ increased the compressive strength of concrete cylinder by a ratio of 5.32 and $14.1 \%$ respectively at an age of 28 days, the compressive strength of concrete cylinders with copper waste of cement ratio $10 \%$ and $15 \%$ increased the 
compressive strength of concrete cylinder by a ratio of 20.5 and $23.99 \%$ respectively at an age of 7 days. The compressive strength of concrete cylinder with copper waste of cement ratio $10 \%$ and $15 \%$ increased the compressive strength of concrete cylinder by a ratio of 5.9 and $17.8 \%$ respectively at an age of 28 days.Finally, they were compressive strength of concrete cylinders with steel, aluminum and copper waste of cement ratio $15 \%$ increased the compressive strength of concrete cylinder by a ratio of $44.1 \%$ respectively at an age of 7 days. The compressive strength of concrete cylinder with steel, aluminum and copper waste of cement ratio $15 \%$ increased the compressive strength of concrete cylinder by a ratio of $22.15 \%$ respectively at an age of 28 days as compared with pure concrete.

\section{Conclusion}

The following remarks can be summarized according to the experimental study. The results show that the use of steel waste (Fe15\%) increased compressive strength of concrete by $18.5 \%$ and copper waste by $(\mathrm{Cu} 15 \%)$ increased it by $15.77 \%$, aluminum (A115\%) increased it by $12.95 \%$ and steel waste ( $\mathrm{Fe} 15 \%$ ) increases compressive strength of cement mortar by $9.55 \%$ as compared to pure mixing. Consequently, adding steel waste to concrete gives it a compressive strength of more than the double of its original strength. Finally, using steel waste was recommended to produce light weight concrete with high strength.

\section{Acknowledgement}

Special thanks to Engineer Wajdi Al- Hazaimeh for is helping in the laboratory.

\section{References}

Albaladnews 2016. (Jordanian businessman and engineer Abdul Qutishat).

Al-Jabri, K. S, Taha, R., \& Al-Saidy, A. H. (2011). Effect of copper slag as a fine aggregate on the properties of cement mortars and concrete. Construction and Building Materials, 25(2011), 933-8.

Al-Jabri, K. S., Hisada, M., Al-Oraimi, S. K., \& Al-Saidy, A. H. (2009). Copper slag as sand replacement for high performance concrete. Cement \& Concrete Composites, 31(2009), 483-8.

American Society for Testing Materials ASTM C39/C39M, ASTM C39 / C39M - 17b Standard Test Method for Compressive Strength of Cylindrical Concrete Specimens.

ASTM C109 / C109M - 16a Standard Test Method for Compressive Strength of Hydraulic Cement Mortars (Using 2-in. or [50-mm] Cube Specimens).

ASTM C143 in the United States, IS: 1199 - 1959 in India and EN 12350-2 in Europe.

Brindha, D., \& Nagan, S. (2011). Durability studies on copper slag admixed concrete. Asian Journal of Civil Engineering (Building and Housing), 12(2011), 563-78.

Cement concrete and aggregate Australia.

Common-metals-in-the-construction-industry (The most common of them are carbon steel, aluminum, copper tubing and stainless steel, which each have their particular qualities and ideal uses).

Environmental Collaboration for Sustainability in the Construction Industry: An Exploratory Study in Italy.

Farzadnia, N., Abang, A. A., \& Demirboga, A. R. (2011). Incorporation of mineral admixtures in sustainable highperformance concrete. International Journal of Sustainable Construction Engineering \& Technology, 2(2011). 44-56.

Green building council Australia

\section{HIGH-STRENGTH CONCRETE INCORPORATING COPPER SLAG AND GROUND PUMICE}

Mehta and Monteiro. (1993) Concrete Structure, Properties, and Materials, Prentice-Hall, Inc., Englewood Cliffs, NJ.

Mortar holding weathered bricks (American Scientist Online". Americanscientist.org. Retrieved 2012-11-03, Masonry: the best of Fine homebuilding. Newtown, CT: Taunton Press, 1997. Print. 113, ASTM C 270-51T". ASTM International. Retrieved 10 September 2015).

Nazer, A. S., Pavez, O., \& Rojas, F. (2012). Use of copper slag in cement mortar. Metallurgy and materials, 65(2012), 87-91.

Office of Engineering Construction and Maintenance Division (Materials Branch).

Onuaguluchi, O., \& Eren, Ö. (2012). Cement mixtures containing copper tailings as an additive: durability properties. Materials Research, 15(2012) 1029-36. 
Tarun, R., \& Naik, F. ASCE (Sustainability of Concrete Construction) -ascelibrary.

Vaidya, S. (2011). Allouche EN. Strain sensing of carbon fiber reinforced geopolymer concrete. Materials \& Structures, 44(2011), 1467-75.

Zeghichi, L. The effect of replacement of naturals aggregates by slag products on the strength of concrete. Asian Journal of Civil Engineering (Building and Housing).

\section{Copyrights}

Copyright for this article is retained by the author(s), with first publication rights granted to the journal.

This is an open-access article distributed under the terms and conditions of the Creative Commons Attribution license (http://creativecommons.org/licenses/by/4.0/). 